\title{
Investigation of Gasochromic Rhodium Complexes Regarding Their Reactivity towards $\mathrm{CO}^{+}$
}

\author{
Karina Tarantik ${ }^{1, *}$, Katrin Schmitt ${ }^{1}$, Carolin Pannek ${ }^{1}$, Lutz Miensopust ${ }^{1}$ and \\ Jürgen Wöllenstein ${ }^{1,2}$ \\ 1 Fraunhofer Institute for Physical Measurement Techniques IPM, Freiburg, Germany; \\ katrin.schmitt@ipm.fraunhofer.de (K.S.); carolin.pannek@ipm.fraunhofer.de (C.P.); \\ lutz.miensopust@ipm.fraunhofer.de (L.M.); juergen.woellenstein@ipm.fraunhofer.de (J.W.) \\ 2 Department of Microsystems Engineering-IMTEK, University of Freiburg, Freiburg, Germany \\ * Correspondence: karina.tarantik@ipm.fraunhofer.de; Tel.: +49-761-8857-730 \\ † Presented at the Eurosensors 2017 Conference, Paris, France, 3-6 September 2017. \\ Published: 17 August 2017
}

\begin{abstract}
The detection of the toxic gas carbon monoxide (CO) in the low ppm range is required in different applications. We present a study of the reactivity of different gasochromic rhodium complexes towards the toxic gas carbon monoxide (CO). Therefore, the binuclear rhodium complexes with different ligands were prepared and their influence regarding reaction velocity and sensitivity towards $\mathrm{CO}$ was investigated. The most promising rhodium complex was embedded into a polymer with which glass substrates were coated. The reactivity towards $\mathrm{CO}$ of these layers was also investigated.
\end{abstract}

Keywords: gasochromic; carbon monoxide; gas sensor; rhodium complex

\section{Introduction}

The detection of the toxic gas carbon monoxide (CO) is especially of high relevance in early fire gas detection, but is also constantly monitored in any industrial or private types of furnaces $[1,2]$. The required concentration range is in the low ppm range. Several methods of detecting $\mathrm{CO}$ are known like electrochemical sensing, metal oxide sensors, or IR spectroscopy. Regarding the aim of sensors to become as small as possible, energy-efficient, and low-cost, the approach of detecting gases via gasochromic dyes came to the fore during the last few years. However, fist gasochromic determination of $\mathrm{CO}$ using iodine pentoxide $\left(\mathrm{I}_{2} \mathrm{O}_{5}\right)$ was described in 1929 [3]. Another suitable inorganic compound is based on a silico-molybdate complex with palladium chloride as catalyst [4]. However, the reaction of inorganic compounds with $\mathrm{CO}$ is only reversible in some cases and usually under high energy supply. Better reversibility is given by metal complex dyes like 5,10,15,20-tetraphenylporphyrin iron(III) chloride or 5,10,15,20-tetraphenylporphyrin zinc(II) $[5,6]$. Binuclear rhodium complexes showed a fast and selective reaction towards CO [7-10]. Furthermore, these compounds offer the advantage of a reversible CO reaction. Therefore, we prepared several binuclear rhodium complexes starting from the dimer rhodium(II) acetate. For evaluation of the reaction velocity towards $\mathrm{CO}$, the color change while applying $\mathrm{CO}$ was recorded of both the dissolved rhodium complexes as well as the compounds embedded into a polymer. These results show the opportunity of using rhodium complexes prepared as gas-sensitive layers on glass substrates for the selective and reversible detection of $\mathrm{CO}$ in air. 


\section{Experimental Part}

\subsection{Synthesis of Binuclear Rhodium Complexes}

As indicator for $\mathrm{CO}$ binuclear rhodium complex with different ligands ware synthesized according to a procedure described in literature [8]. By varying the residues of the phosphines three different compounds based on the identical basic structure were obtained (see Figure 1 and Table 1).

Table 1. Ligands of the rhodium compounds $1 \cdot(\mathrm{A})_{2}-3 \cdot(\mathrm{A})_{2}$.

\begin{tabular}{cccc}
\hline Compound & $\mathbf{X}=$ & $\mathbf{R}=$ & $\mathbf{A}=$ \\
\hline $\mathbf{1} \cdot(\mathbf{A})_{2}$ & $\mathrm{p}-\mathrm{OCH}_{3}$ & $\mathrm{CH}_{3}$ & $\mathrm{CH}_{3} \mathrm{CO}_{2} \mathrm{H}$ \\
$\mathbf{2} \cdot(\mathbf{A})_{2}$ & $\mathrm{~m}-\mathrm{CH}_{3}$ & $\mathrm{CH}_{3}$ & $\mathrm{CH}_{3} \mathrm{CO}_{2} \mathrm{H}$ \\
$\mathbf{3} \cdot(\mathbf{A})_{2}$ & $\mathrm{~m}-\mathrm{F}$ & $\mathrm{CH}$ & $\mathrm{CH}_{3} \mathrm{CO}_{2} \mathrm{H}$ \\
\hline
\end{tabular}

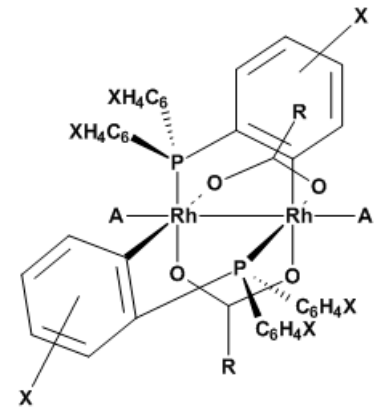

Figure 1. Chemical structure of the colorimetric binuclear rhodium complex $\mathrm{Rh}_{2}\left(\mathrm{O}_{2} \mathrm{CCH}_{3}\right)_{2}\left(\mathrm{P}_{(}\left(\mathrm{C}_{6} \mathrm{H}_{4} \mathrm{X}\right)_{3}\right)_{2} \cdot \mathrm{A}_{2}$ with different ligands (see Table 1).

$0.45 \mathrm{mmol}(200 \mathrm{mg})$ rhodium acetate dimer were dissolved in a mixture of $25 \mathrm{~mL}$ toluene and $5 \mathrm{~mL}$ acetic acid and $0.90 \mathrm{mmol}$ of the corresponding phosphine were added. After refluxing the mixture at $125^{\circ} \mathrm{C}$ for $3 \mathrm{~h}$ the purple solution was cooled to ambient temperature. The solvent was removed under reduced pressure at ambient temperature to yield a deep purple powder.

The rhodium complexes were characterized by FTIR spectroscopy (Bruker ALPHA-T) and differential scanning calorimetry (Netzsch DSC $204 \mathrm{~F} 1$; heat rate $10 \mathrm{~K} / \mathrm{min}^{1}$ ).

1.(A) 2 Yield: 87\%. FTIR (KBr, cm-1): 3432 (w), $3064(\mathrm{vw}), 2995$ (w), 2935 (m), 2903 (w), $2834(\mathrm{~m})$, 2618 (vw), 2543 (w), 2050 (w), 1893 (w), 1678 (s), 1592 (vs), 1566 (vs), 1502 (vs), 1485 (s), 1429 (s), 1404 (s), 1366 (m), 1342 (m), 1287 (vs), 1249 (vs), 1218 (s), 1179 (vs), 1121 (m), 1096 (s), 1028 (s), 941 (w), 862 (w), $825(\mathrm{~s}), 796(\mathrm{~s}), 717(\mathrm{w}), 689(\mathrm{~m}), 619(\mathrm{~m}), 598(\mathrm{w}), 547(\mathrm{~s}), 501(\mathrm{~m}), 466(\mathrm{~m}), 432(\mathrm{~m})$. DSC: $149{ }^{\circ} \mathrm{C}$ (dec.).

2.(A) 2 Yield: 92\%. FTIR (KBr, cm $\left.{ }^{-1}\right): 3432(\mathrm{w}), 3050(\mathrm{vw}), 3009(\mathrm{w}), 2918(\mathrm{~m}), 2862(\mathrm{w}), 2618(\mathrm{vw})$, 2548 (w), 2355 (vw), 1678 (vs), 1569 (s), 1474 (m), 1446 (s), 1410 (s), 1367 (m), 1335 (m), 1294 (s), 1243 (m), $1219(\mathrm{vw}), 1172(\mathrm{w}), 1138(\mathrm{w}), 1107(\mathrm{~m}), 1083(\mathrm{w}), 1024(\mathrm{~m}), 994(\mathrm{vw}), 940(\mathrm{vw}), 869(\mathrm{w}), 815(\mathrm{~m})$, $777(\mathrm{~m}), 724(\mathrm{w}), 693(\mathrm{~s}), 631(\mathrm{vw}), 612(\mathrm{vw}), 558(\mathrm{~m}), 530(\mathrm{w}), 469(\mathrm{~s}), 431(\mathrm{vw})$. DSC: $214^{\circ} \mathrm{C}(\mathrm{dec}$ ).

3.(A) 2 Yield: 97\%. FTIR (KBr, cm-1): 3432 (w, b), 3064 (w), 2927 (w, b), 2678 (vw), 2620 (w, b), 2554 (w, b), 2358 (vw), 1671 (vs), 1600 (m), 1576, (vs), 1475 (s), 1417 (vs), 1364 (m), 1342 (m), 1295 (m), 1262 (m), $1244(\mathrm{~s}), 1217(\mathrm{vs}), 1186(\mathrm{~m}), 1164(\mathrm{w}), 1138(\mathrm{vw}), 1117(\mathrm{w}), 1096(\mathrm{~m}), 1067(\mathrm{w}), 1046$ (vw), 1024 (m), $997(\mathrm{w}), 893(\mathrm{~m}), 876(\mathrm{~m}), 820(\mathrm{w}), 783(\mathrm{~m}), 720(\mathrm{w}), 687(\mathrm{vs}), 631(\mathrm{vw}), 614(\mathrm{w}), 591(\mathrm{~m}), 573(\mathrm{~m})$, $523(\mathrm{~m}), 493(\mathrm{~s}), 453(\mathrm{w}), 414(\mathrm{w})$. DSC: $231^{\circ} \mathrm{C}(\mathrm{dec}$.

\subsection{Fabrication of the Gas-Sensitive Layers}

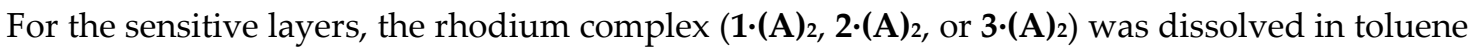
or chloroform $\left(\mathrm{CHCl}_{3}\right)$ and mixed with a solution containing the matrix ethyl cellulose (EC) and the plasticizer tributyl phosphate (TBP). In Table 2 the composition of the solution for the preparation of the sensitive layers is given. 
Table 2. Composition of the solution with the colorimetric compounds.

\begin{tabular}{|c|c|}
\hline Solution \# & Composition \\
\hline S1 & $5 \mathrm{mg} \mathbf{1} \cdot(\mathbf{A})_{2}$ in $1 \mathrm{~mL} \mathrm{CHCl} 3+5 \mathrm{~mL}$ matrix solution $(750 \mathrm{mg} \mathrm{EC}, 750 \mathrm{~mL}$ TBP, $30 \mathrm{~mL}$ ethanol) \\
\hline S2 & $6 \mathrm{mg} \mathbf{2 \cdot ( A})_{2}$ in $1 \mathrm{~mL}$ toluene $+3 \mathrm{~mL}$ matrix solution (750 mg EC, $750 \mathrm{~mL}$ TBP, $30 \mathrm{~mL}$ toluene) \\
\hline S3 & $6 \mathrm{mg} 3 \cdot(\mathrm{A})_{2}$ in $1 \mathrm{~mL}$ toluene $+3 \mathrm{~mL}$ matrix solution (750 $\mathrm{mg}$ EC, $750 \mathrm{~mL}$ TBP, $30 \mathrm{~mL}$ toluene) \\
\hline S4 & $12 \mathrm{mg} \mathbf{1} \cdot(\mathbf{A})_{2}+1 \mathrm{~mL}$ matrix solution $(750 \mathrm{mg} \mathrm{EC}, 750 \mathrm{~mL}$ TBP, $30 \mathrm{~mL}$ toluene) \\
\hline S5 & $11 \mathrm{mg} 2 \cdot(\mathbf{A})_{2}+1 \mathrm{~mL}$ matrix solution (750 $\mathrm{mg} \mathrm{EC}, 750 \mathrm{~mL}$ TBP, $30 \mathrm{~mL}$ toluene) \\
\hline S6 & $11 \mathrm{mg} 3 \cdot(\mathrm{A})_{2}+1 \mathrm{~mL}$ matrix solution (750 $\mathrm{mg} \mathrm{EC}, 750 \mathrm{~mL}$ TBP, $30 \mathrm{~mL}$ toluene) \\
\hline
\end{tabular}

Each solution was pipetted onto glass substrate to investigate the drying behavior regarding homogeneity, transparency, and adhesion. By varying the solution amount and repeating the process, different thicknesses between $5 \mu \mathrm{m}$ and $40 \mu \mathrm{m}$ could be obtained.

\subsection{Gas Sensing Experiments}

To investigate the spectral response of the deposited colorimetric layers, the solution was pipetted onto a glass window of a gas-tight cell for measurements in an UV-VIS spectrometer (Lambda900, Perkin Elmer). The solution was dried for $24 \mathrm{~h}$ and exposed to $200 \mathrm{ppm} \mathrm{CO}$ for $60 \mathrm{~min}$ at a gas flow of $1 \mathrm{~L} / \mathrm{min}$. For all measurements shown are relative humidity of $40 \%$ was given.

\section{Results and Discussion}

Upon CO exposure, the rhodium complexes change theirs colour from purple through red and orange to yellow. The spectral response from $250 \mathrm{~nm}$ to $850 \mathrm{~nm}$ of $11 \mathrm{mg} \mathrm{1 \cdot (A)})_{2}$ dissolved in $8 \mathrm{~mL}$ chloroform before and after exposure to CO (200 ppm, $8 \mathrm{~min})$ is depicted in Figure 2 .

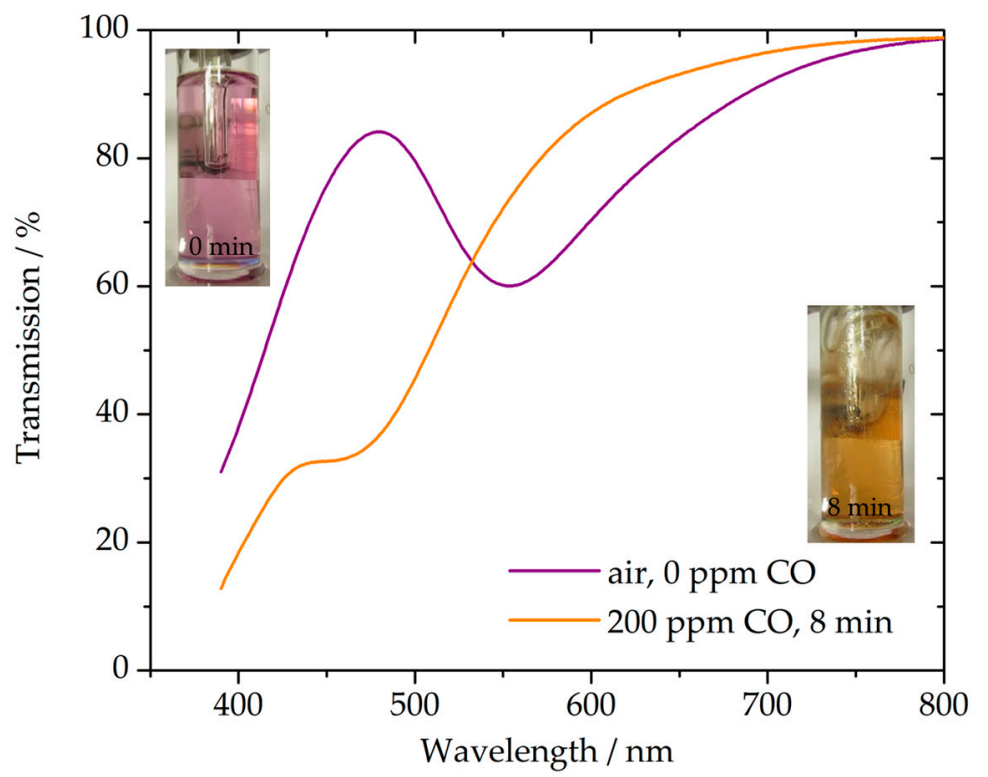

Figure 2. Spectral response of rhodium complex 1.(A) 2 (11 mg dissolved in $\left.8 \mathrm{~mL} \mathrm{CHCl}_{3}\right)$ before (purple) and after exposure to $\mathrm{CO}$ (yellow) [10].

The colour change of the prepared rhodium complexes is caused by a reversible two-step ligand exchange depicted in Figure 3. 

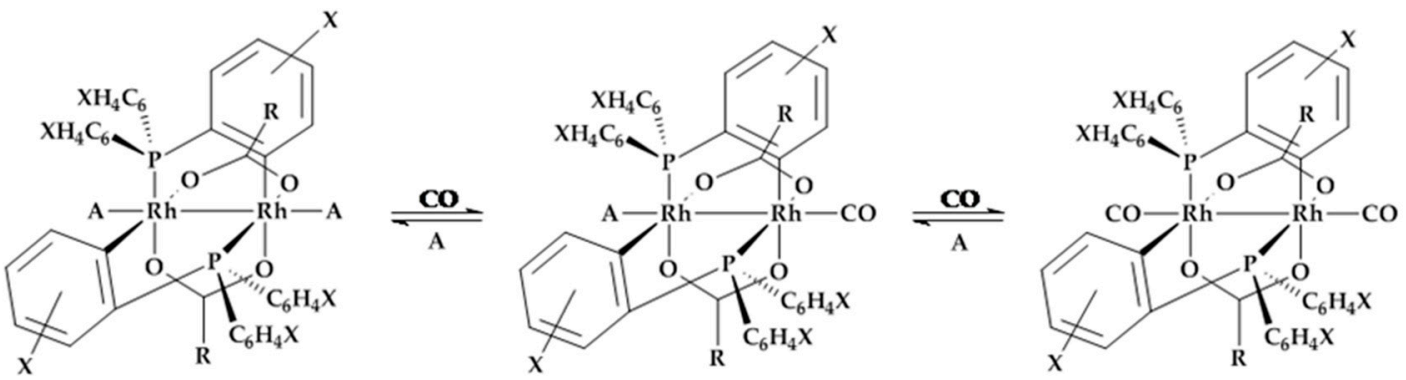

Figure 3. Reaction scheme of the rhodium complex with CO.

All rhodium complexes 1·(A) $\left.)_{2}-3 \cdot(A)\right)_{2}$ were dissolved in toluene $(10 \mathrm{mmol}$ in $15 \mathrm{~mL})$ and exposed to $200 \mathrm{ppm}$ CO for $10 \mathrm{~min}$. Thereby, all solutions turned from purple through orange to yellow.

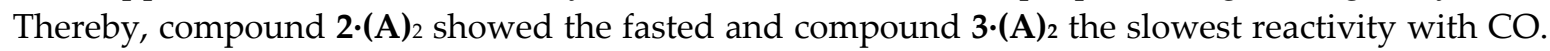
This can be explained by the more or less electron donating residues $\mathrm{X}$ of the phosphine ligands. In all cases a much slower reverse reaction was observed after stopping CO exposure.

Furthermore, the prepared layers from solutions S1-S6 onto UV/VIS glasses were characterized via UV/VIS spectroscopy. As expected, the reaction of embedded rhodium complexes with $\mathrm{CO}$ is much slower than in solution even at higher CO concentrations (Figure 4).

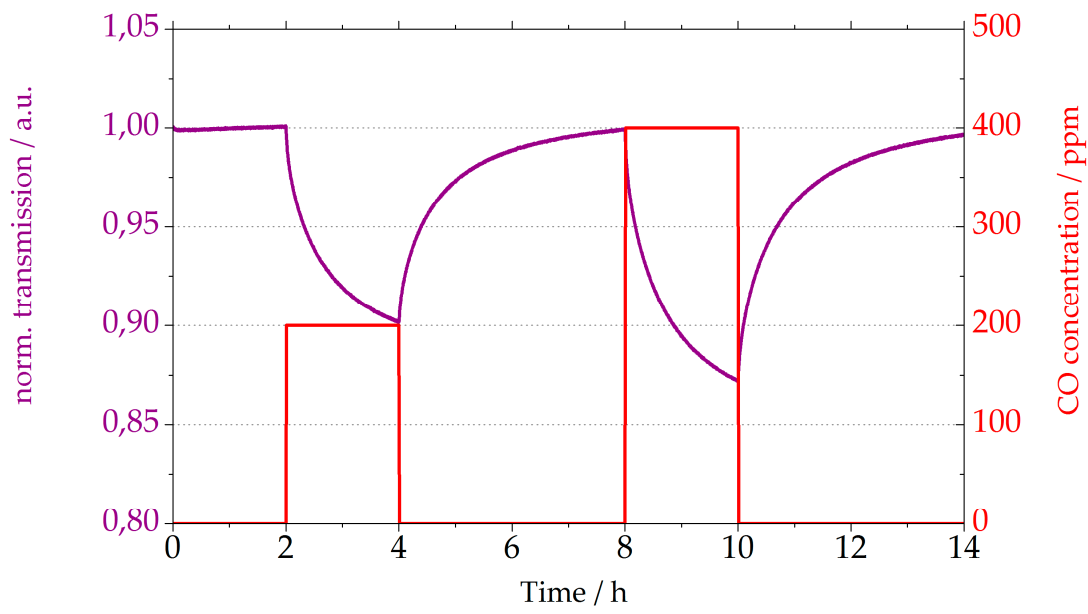

Figure 4. Normalized transmission change at $420 \mathrm{~nm}$ of 1.(A) $)_{2}$ in EC (S1) at 200 and $400 \mathrm{ppm}$ CO [10].

\section{Conclusions}

Three gasochromic binuclear rhodium complexes were prepared and characterized. Their reaction velocity towards $\mathrm{CO}$ was recorded of both the dissolved compounds as well as embedded into a polymer. These results show the opportunity of using rhodium complexes prepared as gassensitive layers on glass substrates for the selective and reversible detection of $\mathrm{CO}$ in air.

Acknowledgments: We acknowledge financial support from the German Federal Ministry of Education and Research (BMBF-FKZ 13N14076).

Conflicts of Interest: The authors declare no conflict of interest.

\section{References}

1. Jackson, M.; Robins, I. Gas sensing for fire detection: Measurements of $\mathrm{CO}, \mathrm{CO}_{2}, \mathrm{H}_{2}$, $\mathrm{O}_{2}$, and smoke density in European standard fire tests. Fire Saf. J. 1994, 22, 181-205. doi:10.1016/0379-7112(94)90072-8.

2. Courbat, J.; Pascu, M.; Gutmacher, D.; Briand, D.; Wöllenstein, J.; Hoefer, U.; de Rooij, N.F. A colorimetric CO sensor for fire detection. Procedia Eng. 2011, 25, 1329-1332. doi:10.1016/j.proeng.2011.12.328.

3. Martinek, M.J.; Marti, W.C. Modified Iodine-Pentoxide Method for Determination of Carbon Monoxide in Air and Blood. Am. J. Public Health Nations Health 1929, 19, 293-298. 
4. Shepherd, M. Rapid determination of small amounts of carbon monoxide. Anal. Chem. 1947, 19, 77-81.

5. Paul, S.; Amalraj, F.; Radhakrishnan, S. CO sensor based on polypyrrole functionalized with iron porphyrin. Synth. Met. 2009, 159, 1019-1023. doi:10.1016/j.synthmet.2009.01.018.

6. Filippini, D.; Alimelli, A.; di Natale, C.; Paolesse, R.; D'Amico, A.; Lundström, I. Chemical sensing with familiar devices. Angew. Chem. 2006, 118, 3884-3887, doi:10.1002/anie.200600050.

7. Esteban, J.; Ros-Lis, J.V.; Martínez-Máñez, R.; Marcos, M.D.; Moragues, M.; Soto, J.; Sancenón, F. Sensitive and selective chromogenic sensing of carbon monoxide by using binuclear rhodium complexes. Angew. Chem. 2010, 49, 4934-4937, doi:10.1002/anie.201001344.

8. Moragues, M.E.; Esteban, J.; Ros-Lis, J.V.; Martínez-Máñez, R.; Marcos, M.D.; Martínez, M.; Sancenón, F. Sensitive and selective chromogenic sensing of carbon monoxide via reversible axial CO coordination in binuclear rhodium complexes. J. Am. Chem. Soc. 2011, 133, 15762-15772. doi:10.1021/ja206251r.

9. Moragues, M.E.; Esteban, J.; Ros-Lis, J.V.; Martínez-Máñez, R.; Marcos, M.D.; Martínez, M.; Sancenón, F. An optoelectronic sensing device for $\mathrm{CO}$ detection in air based on a binuclear rhodium complex. Sens. Actuators B Chem. 2014, 191, 257-263. doi:10.1016/j.snb.2013.09.107.

10. Pannek, C. Mikrosystem zur Brandgasdetektion nach dem Farbumschlagsprinzip. Dissertation, ISBN: 9783-86247-516-2.

(C) 2017 by the authors. Licensee MDPI, Basel, Switzerland. This article is an open access article distributed under the terms and conditions of the Creative Commons Attribution (CC BY) license (http://creativecommons.org/licenses/by/4.0/). 